\title{
The Implementation of Scientific Approach in Improving Social Science Learning on The Theme of The Beauty of Diversity in My Country in 4th Grade Students of SD Negeri 2 Karangkembang in Academic Year 2020/2021
}

\section{Musfik Wahyu Sofiyulloh}

Universitas Sebelas Maret

muzfiqwahyu2@gmail.com

\section{Article History}

received 30/4/2021

revised 30/5/2021

accepted 30/6/2021

\begin{abstract}
Social Sciences is one of the subjects given starting from elementary school. This study aimed: (1) to describe the steps on the implementation of scientific approach in improving social science learning, (2) to improve social science learning with the theme of The Beauty Of Diversity in My Country through the implementation of scientific approach in the 4th grade students of SD Negeri 2 Karangkembang,(3) to describe problems and solutions on the implementation of scientific approach in the 4th students of SD Negeri 2 Karangkembang. This research is a collaborative classroom action research. Each cycle consists of planning, action, observation, and reflection. Techniques of collecting data were test and non-test. The result of this research indicated the implementation of scientific approach could improve social science learning with the theme of The Beauty of Diversity in My Country in 4th grade students of SD Negeri 2 Karangkembang in academic year 2020/2021.
\end{abstract}

Keywords: Scientific Approach, Social Science Learning, Elementary School

\begin{abstract}
Abstrak
IImu Pengetahuan Sosial (IPS) merupakan salah satu mata pelajaran yang diberikan mulai dari sekolah dasar. Penelitian ini bertujuan: (1) untuk mendeskripsikan langkah-langkah penerapan pendekatan saintifik dalam meningkatkan pembelajaran IPS, (2) meningkatkan pembelajaran IPS dengan tema Indahnya Keragaman di Negeriku melalui penerapan pendekatan saintifik pada siswa kelas IV SD Negeri 2 Karangkembang, dan (3) mendeskripsikan masalah dan solusi pada penerapan pendekatan saintifik pada siswa kelas IV SD Negeri 2 Karangkembang. Penelitian ini adalah penelitian tindakan kelas kolaboratif. Setiap siklus terdiri dari perencanaan, tindakan, observasi, dan refleksi. Teknik pengumpulan data adalah tes dan non-tes. Hasil penelitian ini menunjukkan bahwa penerapan pendekatan saintifik dapat meningkatkan pembelajaran IPS tema Indahnya Keragaman di Negeriku pada siswa kelas IV SD Negeri 2 Karangkembang pada tahun ajaran 2020/2021.
\end{abstract}

Kata kunci: Pendekatan Saintifik, Pembelajaran IPS, Sekolah Dasar 


\section{PENDAHULUAN}

Pada abad 21 ini dibutuhkan sistem pendidikan yang mampu menciptakan sumber daya manusia yang berkualitas, yaitu pribadi yang mandiri, berkemauan dan berkemampuan untuk mewujudkan cita-cita bangsanya. Salah satu upaya untuk meningkatkan kualitas SDM melalui pendidikan diperlukan perbaikan terhadap sistem pendidikan terutama kompetensi yang mendukung tugas seorang guru sebagai pendidik. Sagala (2013: 61) mengemukakan bahwa indikator kesuksesan proses pembelajaran terletak pada kesiapan guru dalam mengenal karakteristik siswa.

Salah satu mata pelajaran yang yang diatur dalam Peraturan Menteri Pendidikan Nasional (Permendiknas) yaitu IImu Penge-tahuan Sosial (IPS). Ilmu Penge-tahuan Sosial (IPS) merupakan salah satu mata pelajaran yang diberikan mulai dari SD/MI. Pendidikan IPS memiliki beberapa program yang komprehensif. Program tersebut terdiri dari empat dimensi, yaitu: dimensi pengetahuan, dimensi keterampilan/skills, dimensi nilai dan sikap/values and attitudes, dan dimensi tindakan/action (Sapriya, 2014: 48).

Berdasarkan hasil observasi yang dilakukan pada hari Jumat tanggal 20 November 2020, guru dalam melakukan kegiatan pembelajaran menggunakan buku paket sebagai sumber belajar tanpa melibatkan lain dalam menyampaikan materi kepada siswa. Selain melakukan observasi, peneliti juga melakukan interview kepada guru kelas IV SD Negeri 2 Karangkembang. Menurut guru kelas IV SD Negeri 2 Karangkembang, materi IPS tergolong materi yang sulit untuk dipahami oleh peserta didik karena muatan materinya yang luas serta sebagian besar merupakan materi hafalan yang membutuhkan daya ingat yang baik.

Berdasarkan data hasil Penilaian Tengah Semester (PTS) menunjukkan bahwa tingkat pe-mahaman siswa terhadap mata pelajaran IPS masih rendah yakni belum mencapai Kriteria Ketuntasan Minimal (KKM). KKM yang ditetapkan untuk mata pelajaran IPS adalah 66. Dari data yang diperoleh untuk kelas IV yang terdiri dari 25 siswa hanya 11 siswa atau sebesar $44 \%$ saja yang mendapatkan nilai di atas KKM 66, sedangkan yang mendapat nilai di bawah KKM sebanyak 14 siswa atau sebesar $56 \%$. Berdasarkan data tersebut terlihat bahwa hasil belajar IPS di kelas 4 SDN 2 Karangkembang tergolong rendah sehingga membutuhkan sebuah penanganan khusus yaitu sebuah pembelajaran yang melibatkan peserta didik berperan aktif dalam menemukan informasi, salah satunya yaitu dengan penerapan pendekatan saintifik.

Melelaui pembelajaran dengan pendekatan saintifik diharapkan mampu merubah kualitas pembelajaran dan hasil belajar peserta didik. Berkenaan dengan pendekatan saintifik, Hosnan (2016: 34) berpendapat bahwa pendekatan saintifik adalah konsep pembelajaran yang dibuat agar peserta didik aktif membangun konsep, hukum atau prinsip yang dilakukan dengan beberapa tahapan yang meliputi: mengamati, merumuskan masalah, merumuskan hipotesis, mengumpulkan data, menganalisis data, menarik kesimpulan, dan mengkomunikasikan, Pendapat tersebut didukung oleh Gerde, Schachter, dan Wasik (2013: 315) yang menjelaskan bahwa penggunaan metode ilmiah untuk mengeksplorasi ilmu pengetahuan kepada anak-anak dengan memberikan cara yang sistematis agar menarik atau melibatkan anak dalam kegiatan mengamati, menanya, memprediksi, mencoba, meringkas, dan menyampaikan hasil. Berkenaan dengan pendekataan saintifik, Zhong (2014: 1507-1508) dalam penelitiannya menjelaskan bahwa pendekatan saintifik tidak hanya dapat merangsang perhatian siswa dan memperbaiki pengaruh pengajaran, tetapi juga melatih kemampuan belajar mandiri dan kemampuan inovatif siswa. Hal ini dapat memungkinkan mereka untuk menggunakan metode berpikir ilmiah agar dapat meningkatkan kemampuan memecahkan masalah.

Meskipun demikian, pendekatan saintifik perlu didukung dengan media lain, salah satunya yaitu media video. Media video merupakan media elektronik yang memberikan sebuah pengalaman berupa gambar bergerak dan suara yang dapat 
ditangkap oleh alat indra siswa. Daryanto (2013: 87) menjelaskan bahwa media video adalah bahan ajar non cetak yang memiliki banyak informasi dengan menyajikan gambar bergerak disertai dengan suara dan secara langsung dapat sampai kehadapan siswa. Sementara itu, Asyhar (2011: 74) mengatakan, "media video merupakan rekaman gambar dan suara dalam kaset pita video ke dalam pita magnetik". Dalam peggunaannya media video juga tidak rumit dan membutuhkan banyak biaya yang besar. Guru dapat menayangkan sebuah video pembelajaran yang menarik untuk menambah semangat siswa dalam proses pembelajaran.

Pembelajaran terjadi jika terjalin suatu interaksi antara individu dengan lingkungan sekitar. Rusmono (2014: 6) menyatakan bahwa pem-belajaran merupakan sebuah upaya dalam menciptakan suatu kondisi bagi terciptanya suatu proses belajar yang memungkinkan siswa memperoleh pengalaman belajar yang memadai. Lebih lanjut, menurut Hamdani (2011: 23), pem-belajaran merupakan usaha sadar seorang tenaga pendidik dalam proses pembentukan kepribadian atau tingkah laku yang diharapkan dengan menyediakan lingkungan sebagai sumber belajar. Dari pendapat tersebut dapat disimpulkan bahwa pembelajaran adalah upaya dalam menciptakan suatu kondisi bagi terciptanya suatu proses belajar guna mencapai tujuan pembelajaran dalam proses pembentukan ke-pribadian atau tingkah laku dengan menye-diakan lingkungan sebagai stimulus yang memungkinkan ter-jadinya proses belajar.

IImu Pengetahuan Sosial (IPS) sangat berperan dalam mendukung pembelajaran konsep-konsep dasar ilmu sosial. Susanto (2014: 10) mengatakan, "IPS adalah bidang studi yang mempelajari, menelaah, menganalisis gejala, dan masalah sosial di masyarakat dengan meninjau dari berbagai aspek kehidupan atau satu perpaduan". Lebih lanjut, Buchari Alma dalam Susanto (2013: 141) menyatakan IPS adalah suatu program pendidikan yang mengkaji kehidupan manusia, baik lingkungan alam fisik maupun lingkungan sosial dari perpaduan ilmu sosial, seperti: geografi, sejarah, ekonomi, antropologi, sosiologi, politik, dan psikologi. Berdasarkan kedua pendapat tersebut dapat disimpulkan bahwa IPS adalah ilmu pengetahuan yang mengkaji masalah dan gejala sosial di masyarakat, baik lingkungan alam fisik maupun lingkungan sosial dan berasal dari penggabungan cabang ilmu sosial, seperti: geografi, sejarah, ekonomi, antropologi, sosiologi, politik, dan psikologi.

Berdasarkan uraian di atas, peneliti tertarik untuk melakukan penelitian tindakan kelas dengan judul "Penerapan Pendekatan Saintifik dengan Media Video dalam Peningkatan Pembelajaran IPS Tema Indahnya Keragaman di Negeriku pada siswa kelas IV SD Negeri 2 Karangkembang Tahun Ajaran 2020/2021".

\section{METODE}

Penelitian tindakan kelas ini dilaksanakan di SD Negeri 2 Karangkembang. yang berlokasi di Desa Karangkembang Kecamatan Alian Kabupaten Kebumen. Subjek penelitian tindakan kelas ini adalah siswa kelas IV SD Negeri 2 Karangkembang. Jumlah siswa kelas IV adalah 25 siswa terdiri dari 11 siswa laki-laki dan 14 siswa perempuan. Jenis data pada penelitian tindakan kelas ini terdiri dari dua macam, yaitu data kualitatif dan data kuantitatif.

Dalam mengumpulkan data peneliti menggunakan teknik tes dan teknik non tes .Dalam penelitian ini peneliti menggunakan teknik triangulasi, yaitu triangulasi sumber dan triangulasi teknik. "Triangulasi sumber berarti, untuk mendapatkan data dari sumber yang berbeda-beda dengan teknik yang sama" (Sugiyono, 2016: 330). Sedangkan triangulasi teknik digunakan untuk menjaga kevalidan data. Triangulasi teknik dilakukan untuk menguji kredibilitas data dengan cara mengecek data kepada sumber yang sama dengan teknik yang berbeda. Bentuk analisis data dalam penelitian ini menggunakan model Miles dan Huberman (Sugiyono,2016: 337-345) yang meliputi tiga alur yaitu reduksi data, penyajian data, dan kesimpulan. 
Indikator kinerja dari penelitian ini adalah peningkatan pembelajaran IPS Tema Indahnya Keragaman di Negeriku dengan target 85\%. Prosedur penelitian yang digunakan sesuai dengan yang dikemukakan oleh Kemmis dan MC. Taggart (Arikunto, 2014: 137), yaitu: perencanaan, pelaksanaan, observasi, dan refleksi tindakan.

\section{HASIL DAN PEMBAHASAN}

Kegiatan penelitian ini dilaksanakan dalam dua siklus dengan dua pertemuan. Adapun langkah pembelajaran yang dilakukan yaitu: (1) pemilihan topik, (2) perencanaan kerja sama, (3) implementasi atau investigasi, (4) analisis dan sintesis, (5) presentasi hasil akhir, (6) evaluasi. Hasil observasi siswa dan guru pada penerapan pendekatan saintfik dengan media video dari siklus I sampai II selalu mengalami peningkatan dan telah mencapai indikator penelitian $85 \%$. Begitu pula dengan ketuntasan proses dan hasil belajar siswa.

Tabel 1. Hasil Observasi Penerapan Pendekatan Saintifik

\begin{tabular}{|c|c|c|}
\hline \multirow[b]{2}{*}{ Siklus } & \multicolumn{2}{|c|}{ Observasi } \\
\hline & Guru (\%) & Siswa (\%) \\
\hline I & 73,00 & 70,78 \\
\hline II & 92,78 & 92,72 \\
\hline
\end{tabular}

Tabel 2. Ketuntasan Penilaian Proses dan Hasil Belajar Siswa

\begin{tabular}{ccc} 
Siklus & $\begin{array}{c}\text { Proses } \\
(\%)\end{array}$ & $\begin{array}{c}\text { Penilaian } \\
\text { Hasil } \\
(\%)\end{array}$ \\
\hline I & 64,71 & 58,82 \\
II & 88,24 & 88,24 \\
\hline
\end{tabular}

Berdasarkan data hasil observasi terhadap guru yang diperoleh, pada langkah pertama yaitu mengamati video, guru sudah mampu mengkondisikan kelas dengan baik dengan mempersiapkan media video sebelum pembelajaran dimulai dan menampilkan melalui google meet dengan baik. Oleh karena itu prinsip pengelolaan kelas dapat terlaksana. Hal ini sejalan dengan pendapat Hosnan (2016: 131) yang menyatakan bahwa "Keberhasilan pembelajaran membutuhkan pengelolaan kelas yang baik". Pada langkah menanya sudah dilaksanakan baik meskipun pada awalnya siswa masih bingung apa yang hendak ditanyakan namun setelah dilakukan tindakan dan refleksi tiap pertemuan sehingga siswa mulai aktif bertanya. Hosnan (2016: 49) mengatakan "Bertanya merupakan salah satu pintu masuk untuk memperoleh pengetahuan". Dengan demikian, kegiatan menanya yang dilakukan oleh siswa sangatlah penting untuk menumbuhkan motivasi dalam mengumpulkan informasi.

Langkah selanjutnya yaitu mengumpulkan informasi. Guru mengajak siswa untuk menjawab pertanyaan dari guru serta menanggapi jawaban dari teman lain dengan tujuan agar siswa aktif dalam mengumpulkan informasi karena dilakukan secara bersama. Hal senada diungkapkan Slameto (2013: 165) yang menjelaskan bahwa melalui kelompok diskusi, siswa memiliki kesempatan lebih banyak untuk berinteraksi dengan siswa lain dan guru sehingga akan memberikan pengaruh dan dorongan untuk belajar lebih besar. Pada langkah menalar, siswa sudah baik dalam bekerja sama meskipun ada beberapa siswa yang mendominasi dalam menjawab pertanyaan dari 
guru. Guru sudah mengarahkan siswa agar setiap siswa dapat aktif dalam menanggapi pertanyaan dari teman yang lain. Sependapat dengan Sani (2017: 179) menjelaskan bahwa setiap kelompok perlu memilih ketua kelompok dan menentukan peran masingmasing anggota kelompok.

Langkah terakhir yaitu mengkomunikasikan. Siswa secara bertahap mulai percaya diri untuk bertanya dan menjawab pertanyaan dari siswa lain, menyanggah teman yang memberikan jawaban dan lain sebagainya. Hal demikian sesuai dengan pendapat dari Hosnan (2016: 76) bahwa dalam kegiatan mengkomunikasikan siswa diharapkan dapat mempresentasikan hasil temuannya di depan kelas supaya rasa berani dan percaya diri siswa dapat terarah dengan baik yang dilanjutkan dengan pemberian komentar, saran, atau perbaikan mengenai hasil presentasi temannya.

Dengan demikian, maka disimpulkan bahwa penerapan pendekatan saintifik dengan media video yang dilaksanakan oleh guru dan siswa sudah dilaksanakan dengan sangat baik serta indikator kinerja penilitian yang ditetapkan dengan persentase $85 \%$ juga sudah tercapai.

Penerapan pendekatan saintifik dengan media video dapat meningkatkan pembelajaran IPS tema Indahnya Keragaman di Negeriku. Pada siklus I persentase ketuntasan hasil belajar siswa mencapai $58,82 \%$ dan persentase ketuntasan penilaian proses $64,71 \%$. Peningkatan tersebut terjadi karena penerapan pendekatan saintifik dengan media video yang dilaksanakan oleh guru dapat dilaksanakan dengan baik meskipun pada siklus I belum mencapai indikator kinerja penelitian. Kemudian setelah melaksanakan refleksi pada siklus I dengan memperhatikan kendala pada siklus I, peneliti merencanakan tindakan pada siklus II. Pelaksanaan tindakan pada siklus II meningkat dengan persentase ketuntasan hasil belajar menjadi $88,24 \%$ dan ketuntasan proses belajar $88,24 \%$.

Berdasarkan data hasil observasi terhadap guru dan siswa kemudian diperkuat dengan meningkatnya hasil penilaian proses dan hasil belajar maka penelitian tindakan kelas melalui penerapan pendekatan saintifik dengan media video sudah dilaksanakan dengan baik dan mencapai indikator kinerja penelitian 85\% yang ditetapkan oleh peneliti. Dengan demikian penerapan pendekatan saintifik dengan media video terbukti dapat meningkatkan pembelajaran IPS tema Indahnya Keragaman di Negeriku pada Siswa Kelas IV SD Negeri 2 Karangkembang Tahun Ajaran 2020/2021.

Peningkatan pembelajaran dari siklus I hingga siklus II tersebut sesuai dengan penelitian yang dilakukan oleh Palupi, Suhartono, dan Susiani (2017: 161) yang menunjukkan penggunaan model pembelajaran kooperatif tipe group investigation dengan media video dapat meningkatkan pembelajaran IPS tentang kegiatan ekonomi.

Setiap pertemuan pada siklus I dan II, terdapat kendala baik yang dilakukan oleh guru maupun siswa. Adapun kendala yang dihadapi yaitu: (a) Alat yang lupa belum dilengkapi seperti charger laptop saat melakukan pembelajaran dalam jaringan, (b) waktu sering molor saat pelaksanaan kegiatan pembelajaran karena menunggu siswa yang belum bergabung ke google meet, (c) jaringan kurang stabil, (d) siswa kurang antusias saat mendengar suara guru melalui handphone, (e) masih terdapat beberapa siswa yang memainkan alat tulis dan kurang memperhatikan saat ada teman yang sedang menyampaikan pendapat, ( $f$ ) kualitas sinyal siswa berbeda sehingga terkadang menghambat komunikasi.

Solusi yang dilakukan untuk mengurangi kendala-kendala tersebut yaitu: (a) peneliti menyiapkan peralatan pendukung termasuk memilih tempat yang dekat dengan aliran listrik, (b) peneliti memberikan jadwal pelaksanaan kegiatan pembelajaran melalui google meet sehari sebelum pelaksanaan, (c) peneliti memilih lokasi yang dekat dengan sinyal wifi untuk mencegah terjadinya putus koneksi, (d) guru berkomunikasi dengan intonasi dan gerakan yang membangkitkan semangat siswa, (e) guru memberikan pengarahan dan memberikan pertanyaan kepada siswa yang kurang 
memperhatikan teman yang sedang berpendapat, (f) guru mengulangi dalam menerangkan materi ketika ada siswa yang mengalami kendala sinyal.

Secara umum kendala yang muncul ialah masih kurangnya motivasi siswa untuk mengemukakan pertanyaan. Oleh karena itu, guru harus dapat memberikan suasana yang menarik dan bahasan yang faktual supaya dapat menggugah semangat siswa untuk mengajukan pertanyaan.

\section{SIMPULAN}

Penerapan pendekatan saintifik dengan media video dalam peningkatan pembelajaran IPS Tema Indahnya Keragaman di Negeriku pada siswa kelas IV SD Negeri 2 Karangkembang tahun ajaran 2020/2021 dilaksanakan melalui lima langkah yaitu: (a) mengamati, (b) menanya, (c) mengumpulkan informasi, (d) menalar, dan (e) mengkomunikasikan. Kegiatan pembelajaran sudah dilaksanakan dengan sangat baik, peningkatan pembelajaran ini dibuktikan dengan hasil observasi terhadap guru dan siswa serta hasil penilaian proses dan hasil belajar siswa pada tiap siklusnya yang mengalami peningkatan dan sudah mencapai indikator kinerja penelitian $85 \%$ sesuai target yang ditetapkan oleh peneliti.

Kendala yang ditemui selama pelaksanaan pembelajaran adalah sebagai berikut: : (a) alat yang lupa belum dilengkapi seperti charger laptop saat melakukan pembelajaran dalam jaringan, (b) waktu sering molor saat pelaksanaan kegiatan pembelajaran karena menunggu siswa yang belum bergabung ke google meet, (c) jaringan kurang stabil, (d) siswa kurang antusias saat mendengar suara guru melalui handphone. Solusi yang dilakukan untuk mengurangi kendala-kendala tersebut yaitu: (a) peneliti menyiapkan peralatan pendukung termasuk memilih tempat yang dekat dengan aliran listrik, (b) peneliti memberikan jadwal pelaksanaan kegiatan pembelajaran melalui google meet sehari sebelum pelaksanaan, (c) peneliti memilih lokasi yang dekat dengan sinyal wifi untuk mencegah terjadinya putus koneksi.

\section{DAFTAR PUSTAKA}

Arikunto, S. (2014). Prosedur Penelitian Suatu Pendekatan Praktik. Jakarta: Rineka Cipta.

Asyhar, R. (2011). Kreatif Pengembangan Media Pembelajaran. Jakarta: Gaung Persada Press.

Daryanto. (2013). Media Pembelajaran. Yogyakarta: Gava Media.

Daryanto. (2014). Pendekatan Pembelajaran Saintifik. Kurikulum 2013. Yogyakarta: Gava Media.

Gerde, H.K., Schachter, R.E., \& Wasik, B.A. (2013). Using The Scientific Methode to Guide Learning: An Integrated Approach to Early Childhood Curriculum. Early Chilhood Education Journal, 41 (5), 315-323.

Hamdani. (2011). Strategi Belajar Mengajar. Bandung: CV Pustaka Setia.

Hosnan. (2016). Pendekatan Saintifik dan Kontekstual dalam Pembelajaran Abad 21. Bogor: Ghalia Indonesia.

Palupi, B.S., Suhartono., \& Susiansi, T.S. (2017). Peningkatan Pembelajaran IPS Tentang Kegiatan Ekonomi Melalui Model Pembelajaran Kooperatif Tipe Group Investigation dengan Media Video di Kelas IV SD. Kalam Cendekia, 5 (2.1), 157161.

Rusmono. (2014). Strategi Pembelajaran dengan Problem Based Learning Itu Perlu. Bogor: Ghalia Indonesia.

Sagala, S. (2013). Konsep dan Makna Pembelajaran. Bandung: Alfabeta.

Sapriya. (2014). Pendidikan IPS Konsep dan Pembelajaran. Bandung: PT Remaja Rosdakarya.

Sugiyono. (2016). Metode Penelitian Pendidikan (Pendekatan Kuantitatif, Kualitatif, dan R\&D). Bandung: Alfabeta. 
Supardan. (2015). Pembelajaran Ilmu Pengetahuan Sosial Perspektif Filosofi dan Kurikulum. Jakarta: Bumi Aksara.

Susanto, A. (2013). Teori Belajar dan Pembelajaran di Sekolah Dasar. Jakarta: Kencana.

Susanto, A. (2014). Pengembangan Pembelajaran IPS di Sekolah Dasar. Jakarta: Prenadamedia Group.

Zhong, G.Q. (2014). Training of Scientific Thinking Methods in Teaching of Inorganic and Analytical Chemistry. Journal of Chemical and Pharmaceutical Research, 6 (7), 1503-1508.

Young, R.F. (2007). Crossing Boundaries in Urban Ecology (Doctoral Dissertation). Tersedia dari Proquest Dissertation \& Theses Database.

Kementrian Pendidikan dan Kebudayaan RI. (2011). Peraturan Mendiknas tentang Satuan Pengawasan Internal (Permendiknas Nomor 47 tahun 2011). Jakarta: Penulis. 